\title{
Effect of Ploughing Depth, Tractor Forward Speed, and Plough Types on the Fuel Consumption and Tractor Performance
}

\author{
Kareem Ibrahim Kareem ${ }^{1 *}$, P. Sven ${ }^{2}$ \\ ${ }^{1}$ Department of Field Crop, Khabat Technical Institute, Erbil Polytechnic University, Erbil, Iraqi Kurdistan Region, ${ }^{2}$ Department of Engineering, \\ Harper Adams University, Newport, Shropshire, TF10 8NB, United Kingdom
}

\section{*Corresponding author: Kareem Ibrahim Kareem, Department of Field Crop, Khabat Technical Institute, Erbil Polytechnic University, Erbil, Iraqi Kurdistan Region. Mobile: 7501114579. \\ E-mail: \\ kareem.kareem@epu.edu.iq}

Received: 20 December 2017 Accepted: 10 November 2018 Published: 30 June 2019

\section{DOI}

10.25156/ptj.v9n1y2019.pp43-49

\section{A B S TR A C T}

Cost of fuel has a significant impact on the input costs of agricultural production, especially during primary tillage. It is affected by several parameters including tractor forward speed, depths of ploughing, and plough types. The experiment was performed in a Soil Hall at Harper Adams University, United Kingdom, in April 2015. A Massey Ferguson 8480 4WD tractor was used for investigating objectives of this study. The experiment was performed in a sandy loam soil texture at $11.73 \%$ soil moisture content and $1.35\left(\mathrm{~g} / \mathrm{cm}^{3}\right)$ dry bulk density to study the amount of fuel consumption (I/ha) and the performance of tractor with effect of moldboard and disc ploughs as ploughs type, 15 and $20 \mathrm{~cm}$ as ploughing depth and 5 and $7 \mathrm{~km} / \mathrm{h}$ as tractor forward speeds. The results showed that fuel consumption with a disc plough $5 \%$ was higher compared to the moldboard. Fuel consumption decreased approximately $8 \%$ when tractor at $7 \mathrm{~km} / \mathrm{h}$. Fuel consumption significantly decreased about 34\% when ploughing depth increased from 15 to $20 \mathrm{~cm}$. The power requirement to operate moldboard plough was higher by about $14 \%$ than a disc. The power requirement at speeds of $7 \mathrm{~km} / \mathrm{h}$ was higher compared to the speeds of $5 \mathrm{~km} / \mathrm{h}$ by about $27 \%$. When the depth of ploughing increased from 15 to $20 \mathrm{~cm}$, the power requirement increased by about $1.5 \%$.

Keywords: Depth; Engine performance; Forward speed; Fuel; Plough; Tillage; Tractor

\section{INTRODUCTION}

Agricultural machinery including tractor is considered as one of the most important aspects for operating most agricultural operations and duties (Bell, 1996; Adewoyin and Ajav, 2013). Musa et al. (2012) and Adewoyin and Ajav (2013) reported that agricultural productions were significantly improved since tractors have been used for agricultural operations. The tractor can be described as a power source in the agricultural fields to operate a variety of implements (Mileusnic et al., 2010; Jokiniemi et al., 2012; Yahya et al., 2009). Several agricultural operations are required for different purposes, namely, ploughing, seeding, cultivating, and spraying. Different operations also need special equipment. Bell (1996); Moitzi et al. (2014); and Sahay (2004) have reported that moldboard, disc, chisel, rotary, and subsoiler ploughs are used as main implements for primary tillage operation. Therefore, an agricultural tractor with implements has a significant role in the agricultural sector.

Tillage can be defined as a mechanical soil treatment and preparing suitable conditions for seeds to germinate. Tillage can be classified as primary and secondary (Sahay, 2004; Osman et al., 2011; Abdalla et al., 2014). In addition, Askari and Khalifahamzehghasem (2013) defined tillage as a main agricultural operation. Primary tillage consists of cutting, breaking, returning, and popularizing soil by implements (Ahaneku et al., 2009). Sahay (2004); Al-Suhaibani and Ghaly (2010); Adewoyin and Ajav (2013); and Abdalla et al. (2014) reported that primary tillage operation is used for several objectives. First, it is for cutting soil and seedbed preparation. Second, it is to destroy activities and breeding places of insects and pests. Third, it is to control weeds and fertile soil by converting crop residues. Finally, it is to reduce water and wind erosion also to increase soil aeration and the infiltration rate.

The study was performed to obtain three different aims: First, to determine the effect of depth of ploughing, forward speed of tractor and types of plough on the tractor engine fuel consumption; second, to estimate the performance of tractor with using different depths of ploughing, tractor forward speed, and types of plough; and finally, to find appropriate plough types with less fuel consumption and high engine performance related to the time. 


\section{EFFECTS OF PLOUGHING DEPTH, TRACTOR FORWARD SPEED, AND TYPES OF PLOUGH ON FUEL CONSUMPTION}

Moldboard is the most usable plough for conventional tillage worldwide compared to other types of plough. The greatest amounts of fuel are consumed by moldboard, disc, and chisel ploughs, respectively (Khadr, 2008; Stajnko et al., 2009; Namdari et al., 2011; Moitzi et al., 2014).

The amount of fuel consumption by tractor engines during tillage operation depends on several factors including ploughing depth (Godwin, 2007). There is a liner correlation between the amounts of fuel consumption and ploughing depth, due to increasing soil resistance and volume of soil. Similarly, Moitzi et al. (2006); Khadr (2008); Fathollahzadeh et al. (2009); and Adewoyin and Ajav (2013) investigated that the amount of fuel consumption increased significantly when the ploughing depth increased.

There are different results in research studies about the effect of tractor forward speed on fuel consumption due to the levels of forward speed and engine revolution per minute. Sahay (2004); Khadr (2008); and Gatea (2013) have reported that the amount of fuel consumption and tractor performance was significantly increased when tractor forward speed increased.

Moreover, Kudabo and Gbadmosi (2012) have used Massy Ferguson MF 435 diesel tractor with mounted disc plough for investigating the effect of three levels of forward speed on fuel consumption. The experiment was carried out in a silt clay loamy soil texture at $7.3 \%$ moisture content. Results from Kudabo and Gbadmosi's (2012) study showed that the amount of fuel consumption decreased when tractor forward speed increased from 7 to $10 \mathrm{~km} / \mathrm{h}$ and from 10 to $12 \mathrm{~km} / \mathrm{h}$ at the depth of $15 \mathrm{~cm}$. However, the amount of fuel consumption fluctuated for the same levels of the tractor forward speed, but at the depth of $20 \mathrm{~cm}$.

Effects of Ploughing Depth, Tractor Forward Speed, and Types of Plough on the Performance of Tractor Hunt (2001); Alimardani et al. (2007); and Rashidi et al. (2013) reported that the correlation between depth of ploughing and performance of tractor is non-linear because the mass of soil per cutting unit increases and a higher power is required to pull and operate the implements. In other words, greater amount of power requires if depth of ploughing will increase. For the same purpose, Moeinfar et al. (2014) used a chisel plough for primary tillage at three levels of ploughing depth and reported that the higher level of depth had the greatest influence on increasing draft force. Similar results were shown by Karimiinchebron et al. (2012) when the effect of moldboard plough was measured on drawbar power in a silt clay soil texture at three levels of ploughing depth, namely, 10,15, and $20 \mathrm{~cm}$. Therefore, the greatest power should be applied to operate primary tillage implements at a deeper level.

Rashidi et al. (2013) studied effects of tractor forward speed, depth of ploughing, and soil moisture content on the performance of tractor in clay soil texture and have investigated that the performance of tractor significantly increased when tractor forward speed increased. Similarly, Hunt (2001) indicated that the moldboard plough requires higher power because it returns and pulverizes soil to the higher level. Furthermore, all functions of primary tillage cannot be achieved by other types of plough compared to the moldboard.

Moreover, Gatea (2013) used a moldboard plough with a Tumosan $74 \mathrm{~kW} 2 \mathrm{WD}$ tractor in a clay loam soil texture for investigating power requirement related to the tractor forward speed. The result of Gatea's (2013) study showed that the power requirement increased significantly when tractor forward speed increased from 5.5, 6.3, and $6.3 \mathrm{~km} / \mathrm{h}$, respectively.

\section{MATERIALS AND METHODS}

\section{Design of Experimental Units}

Factorial randomized complete block design (RCBD) was performed differently for both ploughs used (Tables 1 and 2). The experiment was based on three parameters, namely, depth of ploughing, tractor forward speed, and types of plough. Total experimental units carried out were 24 with two levels of ploughing depth, two levels of tractor forward speed, two types of plough, and three replications. Fifteen and $20 \mathrm{~cm}$ were set as depths of ploughing and 5 and $7 \mathrm{~km} / \mathrm{h}$ were set as tractor forward speeds (Tables 1 and 2). Moldboard and disc ploughs were used. The tractor was run at gear 4 during whole units. In other words, at both levels of the tractor, forward speed just RPM of the engine was changed and the gear rang was remained same. Lengths of experiments were approximately $30 \mathrm{~m}$. The actual working width of moldboard and disc ploughs was $80 \mathrm{~cm}$ and $75 \mathrm{~cm}$, respectively.

\section{Experiment Site}

The experiment was performed in a Soil Hall at Harper Adams University on April 20-24, 2015. Harper Adams University is located in Newport, Shropshire, TF10 8NB, United Kingdom, and the site area of the experiment was prepared. The soil texture of the Soil Hall is a sandy loam with $65 \%$ sand, $19 \%$ clay, and $16 \%$ silt (Chyba, 2012). The total area of the Soil Hall was $1800 \mathrm{~m}^{2}$ with $60 \mathrm{~m}$ length and $30 \mathrm{~m}$ width. $540 \mathrm{~m}^{2}$ with $30 \mathrm{~m}$ length and $18 \mathrm{~m}$ width 
Table 1: Randomized complete block design of moldboard plough

\begin{tabular}{llll}
\hline Treatments & \multicolumn{1}{c}{ Blocks } & \\
\cline { 2 - 4 } & Block 1 (Replication 1) & Block 2 (Replication 2) & Block 3 (Replication 3) \\
\hline T1 & Depth $15 \mathrm{~cm}$ and speed $5 \mathrm{~km} / \mathrm{h}$ & Depth $20 \mathrm{~cm}$ and speed $7 \mathrm{~km} / \mathrm{h}$ & Depth15 cm and speed $5 \mathrm{~km} / \mathrm{h}$ \\
T2 & Depth $15 \mathrm{~cm}$ and speed $7 \mathrm{~km} / \mathrm{h}$ & Depth $15 \mathrm{~cm}$ and speed $5 \mathrm{~km} / \mathrm{h}$ & Depth $15 \mathrm{~cm}$ and speed $7 \mathrm{~km} / \mathrm{h}$ \\
T3 & Depth $20 \mathrm{~cm}$ and speed $5 \mathrm{~km} / \mathrm{h}$ & Depth $15 \mathrm{~cm}$ and speed $7 \mathrm{~km} / \mathrm{h}$ & Depth $20 \mathrm{~cm}$ and speed $7 \mathrm{~km} / \mathrm{h}$ \\
T4 & Depth $20 \mathrm{~cm}$ and speed $7 \mathrm{~km} / \mathrm{h}$ & Depth $20 \mathrm{~cm}$ and speed $5 \mathrm{~km} / \mathrm{h}$ & Depth $20 \mathrm{~cm}$ and speed $5 \mathrm{~km} / \mathrm{h}$ \\
\hline
\end{tabular}

Table 2: Randomized complete block design of disc plough

\begin{tabular}{llll} 
Treatments & \multicolumn{3}{c}{ Blocks } \\
\cline { 2 - 4 } & Block 1 (Replication 1) & Block 2 (Replication 2) & Block 3 (Replication 3) \\
\hline T1 & Depth $20 \mathrm{~cm}$ and speed $7 \mathrm{~km} / \mathrm{h}$ & Depth $20 \mathrm{~cm}$ and speed $5 \mathrm{~km} / \mathrm{h}$ & Depth $15 \mathrm{~cm}$ and speed $7 \mathrm{~km} / \mathrm{h}$ \\
T2 & Depth $20 \mathrm{~cm}$ and speed $5 \mathrm{~km} / \mathrm{h}$ & Depth $20 \mathrm{~cm}$ and speed $7 \mathrm{~km} / \mathrm{h}$ & Depth $20 \mathrm{~cm}$ and speed $5 \mathrm{~km} / \mathrm{h}$ \\
T3 & Depth $15 \mathrm{~cm}$ and speed $7 \mathrm{~km} / \mathrm{h}$ & Depth $15 \mathrm{~cm}$ and speed $5 \mathrm{~km} / \mathrm{h}$ & Depth $20 \mathrm{~cm}$ and speed $7 \mathrm{~km} / \mathrm{h}$ \\
T4 & Depth $15 \mathrm{~cm}$ and speed $5 \mathrm{~km} / \mathrm{h}$ & Depth $15 \mathrm{~cm}$ and speed $7 \mathrm{~km} / \mathrm{h}$ & Depth $15 \mathrm{~cm}$ and speed $5 \mathrm{~km} / \mathrm{h}$ \\
\hline
\end{tabular}

of the total Soil Hall area was used as the experiment site. At the front of the Soil Hall, $20 \mathrm{~m}$ of the length was left as a gap so that the tractor could reach the required forward speeds and depths of ploughing. At the rear of the Soil Hall, $10 \mathrm{~m}$ of the length was also left as a safety and end gap for stopping the tractor. In addition, on the upper side, $10.45 \mathrm{~m}$ of the Soil Hall width was left and was not used in the experiment to avoid the compacted area because it was near to the main gate of the Soil Hall. $1.55 \mathrm{~m}$ on the lower side was not used because it was a concrete pathway. Controlled soil moisture content and wind speed; topography and same soil texture were a reason for choosing the Soil Hall as the experimental site.

\section{Tractors}

Two tractors were used during the experiment in the Soil Hall. A Massey Ferguson 8480 Dyna VT 4WD was only used as the main tractor for the primary tillage operation (Figure 1). Appropriate information of Massey Ferguson 8480 Dyna VT tractor is shown in Table 3. The second tractor was used for the purpose of soil preparation and leveling. A fuel flow meter was fitted to the tractor for measuring the amount of fuel used by the engine (Figure 1). The maximum flow rate of fuel flow meter was $60 \mathrm{l} / \mathrm{h}$. The fuel flow meter was located between a fuel pump and fuel injector pump. It measured $1 \mathrm{~cm}^{3}$ of fuel per pulse. It measured only the incoming amount of fuel from the fuel pump because the fuel return line in the injectors was directly connected to the fuel flow meter. As a result, it measured only the correct amount used by the engine. The fuel flow meter was also powered by the tractor battery. External factors such as temperature and humidity did not affect fuel flow meter sensor, due to the experiment carried out in an isolated place which was Soil Hall.

Moreover, two draught force sensing pins were fitted to the right and left lower link arms for measuring draught force. Draught force sensing pins were located between

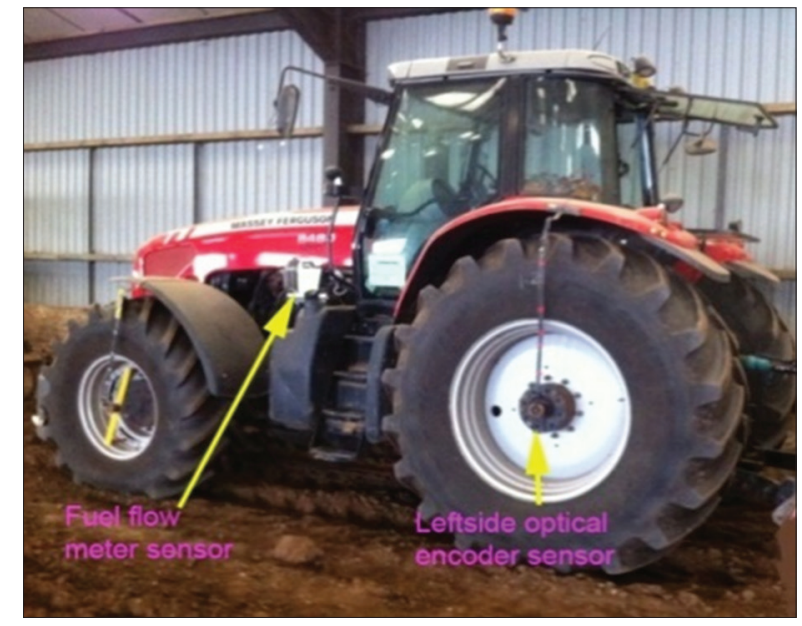

Figure 1: Massey Ferguson 8480 Dyna VT 4WD tractor

the lift rod interface and the implement attachment ball joint along the neutral axis. Draught force sensing pins were directly plugged to the data logger and measured draught force.

Furthermore, two optical encoder sensors with 128 pulses per one revolution were fitted to both the right and left rear wheels to measure revolutions distance of both rear wheels during experiment units. Figure 1 shows the left optical encoder sensor position, and similarly, another optical encoder sensor was fitted to the right rear wheel. Another optical encoder sensor was also installed with a fifth wheel for determining actual distance of experiment units without slippage percentage, due to the fifth wheel was free from slippage.

\section{Data Acquisition}

A data acquisition was set up for recording required data from sensors during the experiment. An eight input National Instrument (NI USB-6008) was used as a data. A Vishay 2120A, X1 gain 5 to 12 VDC, 120 ohm amplifier was also used in the data acquisition. A Vishay amplifier 


\begin{tabular}{|c|c|}
\hline Name & Massey Ferguson \\
\hline Model number of cylinder & 8480 Dyna VT, 6 \\
\hline Engine cubic capacity & $8.4 \mathrm{~L}$ \\
\hline Normal engine power at 2000 rpm & $213 \mathrm{~kW}$ \\
\hline Maximum engine power at $2200 \mathrm{rpm}$ & $231 \mathrm{~kW}$ \\
\hline Maximum engine torque & $1280 \mathrm{Nm}$ \\
\hline Idle speed & 800 rpm \\
\hline Maximum engine speed rate at no load & 2250 rpm \\
\hline Cooling system & Water-cooled \\
\hline Rear tire and inflation pressure & $\begin{array}{c}\text { Michelin } 650 / 85 \text { R } 38 \\
\text { and } 1.2 \text { bar }\end{array}$ \\
\hline Front tire and inflation pressure & $\begin{array}{l}\text { Michelin } 600 / 70 \text { R } 28 \\
\text { and } 1.4 \text { bar }\end{array}$ \\
\hline Weight with full tank & $8500-9200 \mathrm{Kg}$ \\
\hline Length and width & $5.068 \mathrm{M}, 2.550 \mathrm{M}$ \\
\hline Height at roof & $3.197 \mathrm{M}$ \\
\hline $\begin{array}{l}\text { Maximum and minimum clearance } \\
\text { from axel }\end{array}$ & $0.335 \mathrm{M}, 0.477 \mathrm{M}$ \\
\hline
\end{tabular}

Source: MASSEY FERGUSON, 2006

was used to supply power for the fifth wheel and both rear wheel optical encoder sensors. The fifth wheel and rear wheel optical encoder sensors were connected to the Vishay amplifier which was connected to the National Instrument data logger. The Vishay amplifier was powered by the tractor battery. However, the right and left draught force sensing pins, and the fuel flow meter were directly linked to the National Instrument data logger. Power sources of draught force sensing pins and fuel flow meter were National Instrument and tractor battery, respectively. Another channel, which was switched on/off, was used for recording the real time of the experiment units. It was directly connected to the National Instrument data logger. Finally, the National Instrument data logger was connected to a computer. Figure 2 shows the acquisition block diagram which explains the set-up of sensors, logger, amplifier, and computer. Sampling rate 1000 samples per second and five voltages were set for all channels in the data logger.

\section{Implements}

Two primary tillage implements were used during the experiment. The first implement was a KVERNELAND mounted moldboard plough with two bottoms. The second implement was a standard disc plough with two discs. Vertical and horizontal settings were performed for both primary tillage implements used and settings for both ploughs were similar with regard to field parameters. Weight of ploughs did consider as the main parameters.

\section{Soil Preparation}

The soil of the Soil Hall was prepared several times. Due to the limited area, four experiment units were performed per preparation. Limited space of the Soil Hall also was a reason to set up RCBD separately for both ploughs used.

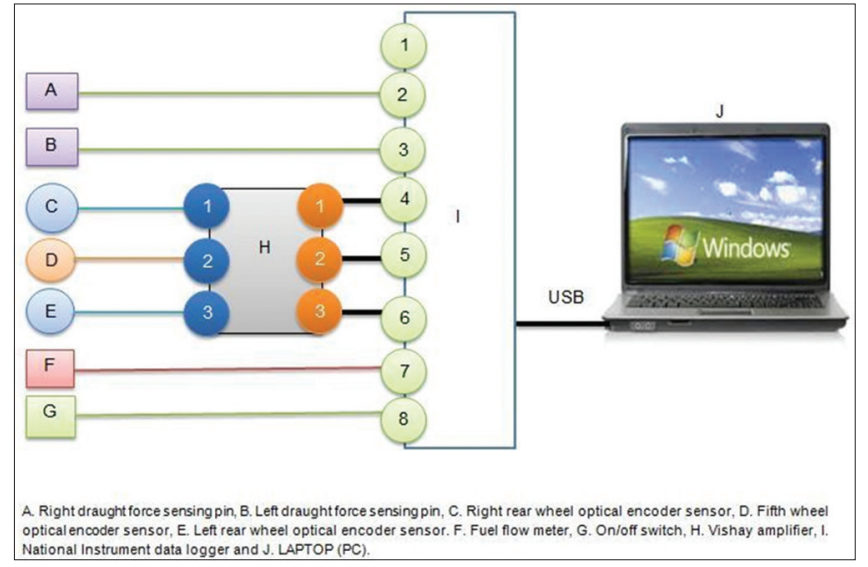

Figure 2: Data acquisition block diagram

A combination of subsoiler, power harrow, and leveler was attached to the second tractor for the purpose of soil preparation. Soil was subsoiled at approximately $30 \mathrm{~cm}$ depth to loosen it. The power harrow was set up behind the subsoiler and used to pulverize the clods produced by the subsoiling. The leveler (roller) was attached to the end of the combined implements and was used to make the soil surface uniform and to compact the topsoil layer. The combination was run twice per preparation.

Furthermore, sticks were placed in the soil at the front and rear of the highlighted experiment area after each soil preparation. The stick was used as a technique for determining the approximate length of the experiment units. The length of the experiment units by this technique was expected about to be $\pm 5 \%$.

The switch on/off button, which is depicted as channel G in Figure 2, was used for recording period of approximate length (distance) of the experiment units. Two people stood near to the front and rear sticks signaling to the third person who recorded time by switching the on/off button. At the front of the field, recording time was started when the rear wheels of the tractor reached the front stick. At the end of the field, recording time was stopped when the rear wheels reached the rear stick. This technique was used for recording time throughout the whole experiment. Disc and moldboard plough experiment units were performed, respectively, at all soil preparation times.

\section{Software}

MATLAB R2014a was used for analyzing raw collected data from data acquisition. Microsoft Excel 2010 was used to analyze some stages of the raw data after analysis by MATLAB R2014a. Microsoft Excel 2010 was also used to generate graphs. The scheme of the Soil Hall was designed using AutoCAD 2010. GenStat $16^{\text {th }}$ edition SP1 (32 bit) software as a statistical tool was used to analysis of variance (ANOVA). 


\section{RESULTS}

General treatment structure in randomized blocks at 0.05 probability level of error was used to ANOVA. Tukey's test was also used to confirm difference between significant factors and observations on power, fuel consumption, and time.

\section{Fuel Consumption}

Figure 3 shows the effect of integration of tractor forward speed, depth of ploughing, and types of plough on the amount of fuel consumption. There are no significant differences in fuel consumption between these three factors, but there is difference between means. The highest and lowest amount of fuel, which is about 52 and $231 /$ ha, was consumed when moldboard plough was used at a speed of $5 \mathrm{~km} / \mathrm{h}$; in a depth of 15 and 20, respectively. The amount of fuel consumption with both types of plough at the depth of $15 \mathrm{~cm}$ increased when the tractor forward speed increased from 5 to $7 \mathrm{~km} / \mathrm{h}$. On the other hand, it decreased at the depth of $20 \mathrm{~cm}$. The difference in fuel consumption between levels of tractor forward speed at the depth of $15 \mathrm{~cm}$ with the disc plough is approximately $54.10 \%$ and is the greatest difference compared to other levels of ploughing depth and types of plough. Overall, Figure 3 shows that the amount of fuel consumption in both types of plough and both levels of tractor forward speed was higher at the depth of $15 \mathrm{~cm}$ compared the depth of $20 \mathrm{~cm}$.

\section{Tractor's Performance}

ANOVA showed that there is no significant difference in the power requirement to pull primary tillage ploughs between observations at (0.05) probability level of error. The grand means of power are $43.24 \mathrm{~kW}$ with 15.3 and $39.6 \%$ coefficients of variation for block and block units, respectively. Although there are no significant differences

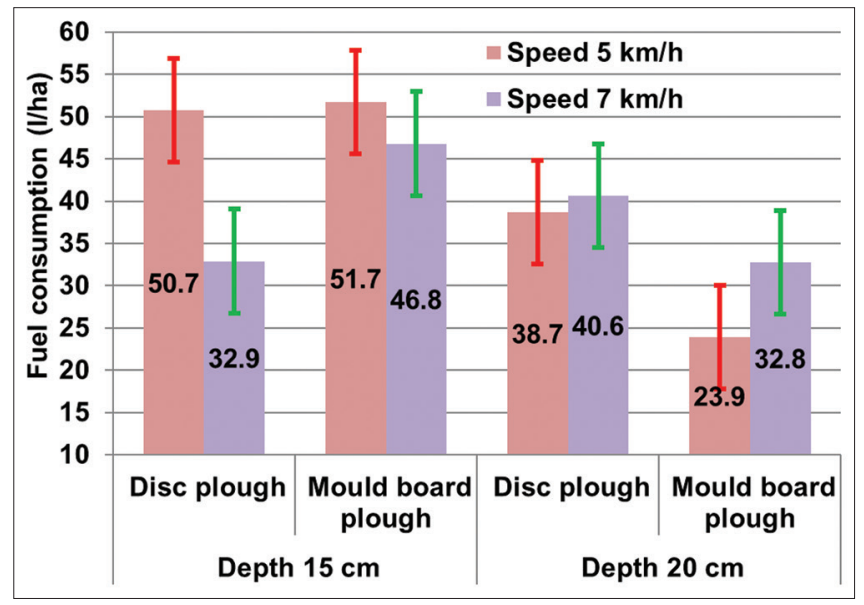

Figure 3: The effect of tractor forward speed, ploughing depth, and types of plough on fuel consumption (I/ha). Error bars are standard errors of mean $=6.13$, degree of freedom $($ d.f $)=14, n=3$ in means of variance illustrated, there are difference effect values of factors on the power requirement.

Figure 4 shows the effect of integration of the tractor forward speed, depth of ploughing, and types of plough on the power requirement for pulling moldboard and disc plough. According to the table of ANOVA, there is no significant difference in the performance of tractor between these three factors, but there is a difference between means. The power requirement at the speed of $5 \mathrm{~km} / \mathrm{h}$ in the depth of $15 \mathrm{~cm}$ for pulling disc and moldboard plough is approximately 42 and $36 \mathrm{~kW}$, receptively. It is also about 31 and $61 \mathrm{~kW}$ at the same depth of ploughing, but at the speed of $7 \mathrm{~km} / \mathrm{h}$. In addition, at the depth of $20 \mathrm{~cm}$ with the speed of $5 \mathrm{~km} / \mathrm{h}$, the power needed to operate disc and moldboard ploughs is approximately 39 and $34 \mathrm{~kW}$, respectively. It is about 49 and $51 \mathrm{~kW}$ at the same working depth but at the speed of $7 \mathrm{~km} / \mathrm{h}$.

Figure 4 shows that the moldboard plough utilized a higher power at the depth of $15 \mathrm{~cm}$ in the speed of $7 \mathrm{~km} / \mathrm{h}$ which is about $61 \mathrm{~kW}$. In contrast, disc plough utilized a higher power at the same speed, but at the depth of $20 \mathrm{~cm}$. Overall, at both levels of ploughing depth and speed $7 \mathrm{~km} / \mathrm{h}$, moldboard plough used a higher power compared to the disc plough.

\section{DISCUSSION}

In general, a higher amount of fuel was consumed when the disc plough was used compared to the moldboard plough. The result is contrary to Khadr (2008); Stajnko et al. (2009); Namdari et al. (2011); and Moitzi et al. (2014) studies. Moldboard plough at the depth of $15 \mathrm{~cm}$ in both levels of tractor forward speed had a higher impact on the amount of fuel consumption compared to the disc plough and this is similar to the Khadr (2008); Stajnko et al. (2009);

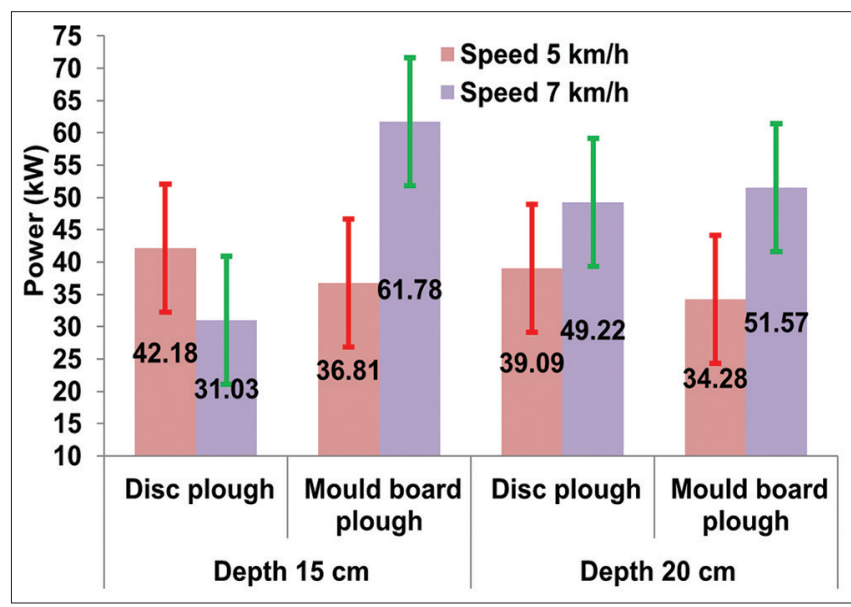

Figure 4: The effect of tractor forward speed, ploughing depth, and types of plough on the performance of the tractor (kW). Error bars are standard errors of mean $=9.897$, degree of freedom (d.f $)=14, n=3$ 
Namdari et al. (2011); and Moitzi et al. (2014) results. On the other hand, it had less effect at the depth of $20 \mathrm{~cm}$.

Regardless of the tractor forward speed and time, using disc plough for primary tillage operation could be effective at the depth of $15 \mathrm{~cm}$ because a lower amount of fuel is consumed compared to the moldboard plough. However, using moldboard plough for the same purpose could be effective at the depth of $20 \mathrm{~cm}$ regardless of the tractor forward speed, due to lower consumption of fuel than disc plough at this level of ploughing depth.

Overall, the amount of fuel consumption with both types of plough decreased when levels of tractor forward speed and ploughing depth increased. Regardless of the disc plough, at the speed of $7 \mathrm{~km} / \mathrm{h}$ increasing the depth of ploughing had a negative influence on the amount of fuel consumption. This result is contrary to Moitzi et al. (2006); Godwin (2007); Khadr (2008); Fathollahzadeh et al. (2009); and Adewoyin and Ajav (2013). Consuming less fuel at a deeper tillage level is effective and crucial for reducing input costs, but it contradicts previous studies and is unreliable because deeper tillage requires a higher power and a higher amount of fuel is needed for producing greater power. Therefore, this result could not be recommended and be used as an effective method for reducing input costs.

In addition, increasing the amount of fuel consumption with increased depth of ploughing could be occurring as a result of several different factors when the experiment units were carried out in the Soil Hall. First, ununiformed soil of the Soil Hall during experiment and uncontrolled other parameters such as soil moisture content and bulk density may be factors. Second, determining ploughing depth set-up method could also be another factor because it was not an accurate method. Finally, tractor driver skill and knowledge may also be another parameter.

Furthermore, at the depth of $15 \mathrm{~cm}$, both types of plough in the speed of $5 \mathrm{~km} / \mathrm{h}$ had a higher effect on the fuel consumption. The result is similar to the Kudabo and Gbadmosi's (2012) study, but it is dissimilar to the Sahay (2004); Khadr (2008); and Gatea's (2013) studies. In terms of the tractor forward speed, the amount of fuel could decrease with increasing levels of forward speed at the same level of ploughing depth. As a result, efficiency of the tractor increases and covers the unit area in a short time. Thus, a disc could be effective at the depth of $15 \mathrm{~cm}$ with the speed of $7 \mathrm{~km} / \mathrm{h}$ regardless of time.

In contrast to the depth of $15 \mathrm{~cm}$, at $20 \mathrm{~cm}$, the speed of $7 \mathrm{~km} / \mathrm{h}$ had a greater impact on fuel consumption with both types of plough. On the other hand, less time was required at the speed of $7 \mathrm{~km} / \mathrm{h}$ for covering the unit of area for both types of plough. The results support the findings of Sahay (2004); Khadr (2008); and Gatea (2013) studies and contradicts those of Kudabo and Gbadmosi's (2012) study. It confirms that higher fuel will be required if the RPM of the engine increases. Hence, according to the results, using moldboard plough at a depth of $20 \mathrm{~cm}$ and speed of $5 \mathrm{~km} / \mathrm{h}$ is effective compared to other levels of tractor forward speed and depths of ploughing.

Although there are no significant differences between factors on the tractor power requirement, because, in general, the power requirement was increased with increasing tractor forward speed and depths of ploughing. Overall, moldboard plough requires a higher power compared to the disc plough. The result is similar to the Alimardani et al. (2007); Karimiinchebron et al. (2012); and Moeinfar et al. (2014) studies. The reason for this result could be lifting and pulverizing the mass of the soil to a higher level by moldboard plough compared to the disc plough.

Regardless of the tractor forward speed, deeper tillage had a significant effect on the power requirements for operating disc plough and is similar to Hunt (2001); Alimardani et al. (2007); and Rashidi et al. (2013) reports because with increasing depth of plough, the mass of soil will increase and it requires a higher power for cutting, lifting, returning, and pulverizing. On the other hand, the higher depth of ploughing did not have a significant effect on the power requirement for operating moldboard plough. The results contradict the findings of Hunt (2001); A limardani et al. (2007); and Rashidi et al. (2013) reports.

The levels of the tractor forward speed had a highly significant effect on the power requirement for operating both types of plough excluding disc plough at the depth of $15 \mathrm{~cm}$ in the speed of $7 \mathrm{~km} / \mathrm{h}$. In general, the results support those of Gatea (2013) and Rashidi et al. (2013) studies. If the tractor runs at a higher then a great power will produce, on the other hand, it cuts much amount of soil per unit time so that is required a higher power.

Regardless of the time, a moldboard plough is effective at the depth of $20 \mathrm{~cm}$ in the speed of $5 \mathrm{~km} / \mathrm{h}$ because the tractor consumes lower amounts of fuel and lower power is required. If time is more important compared to the power requirement and fuel, then the moldboard plough could also be effective at the depth of $20 \mathrm{~cm}$, but in the speed of $7 \mathrm{~km} / \mathrm{h}$. Hence, it depends on the priority of types of operation to which one will be important to the farmer. If tillage window is short, then time will be crucial. On the other hand, if tillage window is longer and fuel prices higher, time will ignore. The same prediction could be applied to the power if the tractor has higher or lower power.

Disc plough could be effective or optimal at the depth of $15 \mathrm{~cm}$ in the speed of $7 \mathrm{~km} / \mathrm{h}$ with regard to all features 
taken into account in this study. All aspects of sustainable development might be probably achieved if tractor is operated with disc plough at the depth of $15 \mathrm{~cm}$ in the speed of $7 \mathrm{~km} / \mathrm{h}$. In addition, it also consumes lower amounts of fuel and covers the unit area in a short time.

There are some differences with literature which may be due to ununiformed of the soil and determining ploughing depth method and requires further investigation of compacting and leveling soil. It is also needs improvement in the method of determining ploughing depth.

\section{CONCLUSION}

Depth and speed are the key parameters that affect performance and fuel consumption and this suggests that by observing and collecting data on the variables will aid optimal tillage. Moldboard plough has an optimal efficiency at the depth of $20 \mathrm{~cm}$ in the speed of $5 \mathrm{~km} / \mathrm{h}$ regards to the fuel consumption and power requirement. The same plough has an optimal efficiency at the depth of $20 \mathrm{~cm}$ in the speed of $7 \mathrm{~km} / \mathrm{h}$ regards time. Disc plough has an optimal efficiency at the depth of $15 \mathrm{~cm}$ in the speed of $7 \mathrm{~km} / \mathrm{h}$ regards to the fuel consumption, power requirement, and time.

\section{REFERENCES}

Abdalla, O. A., E. A. Mohamed, A. M. El Naim, M. A. El Shiekh and M. B. Zaied. 2014. Effect of disc and tilt angles of disc plough on tractor performance under clay soil. Curr. Res. Agric. Sci. 1(3): 83-94.

Adewoyin, A. O. and E. Ajav. 2013. Fuel consumption of some tractor models for ploughing operations in the sandy-loam soil of Nigeria at various speeds and ploughing depths. Agric. Eng. Int. CIGR J. 15(3): 67-74.

Ahaneku, I. E., O. A. Oyelade and T. Faleye. 2009. Comparative field evaluation of three models of a tractor. J. Appl. Sci. Eng. Technol. 7(1): 90-99.

Alimardani, R., Y. Abbaspour-Gilandeh, A. Khalilian, A. Keyhani and S. H. Sadati. 2007. Energy savings with variable-depth tillage "a precision farming practice". Am. Eurasian J. Agric. Environ. Sci. 2(4): 442-447.

Al-Suhaibani, S. A. and A. E. Ghaly. 2010. Effect of plowing depth of tillage and forward speed on the performance of a medium size chisel plow operating in a sandy soil. Am. J. Agric. Biol. Sci. 5(3): 247-255.

Askari, M. and S. Khalifahamzehghasem. 2013. Draft force inputs for primary and secondary tillage implements in a clay loam soil. J. Appl. Sci. Res. 21(12): 1789-1794.

Bell, B. 1996. Farm Machinery. $4^{\text {th }}$ ed. Farming Press Books and Videos Miller Freeman Professional Ltd., United Kingdom.

Chyba, J. 2012. The Influence of Traffic Intensity and Soil Texture on Soil Water Infiltration Rate: Being a Thesis Submitted in Partial Fulfilment of the Requirements for the Msc Engineering. Harper Adams University, Newport.

Fathollahzadeh, H., H. Mobli and S. M. H. Tabatabaie. 2009. Effect of ploughing depth on average and instantaneous tractor fuel consumption with three share disc plough. Int. Agrophys. 23(4): 399-402.

Gatea, A. A. 2013. Influence of tillage pattern and forward speed of the tractor in the efficiency tillage. Int. J. Agric. Sci. Res. 3(4): 109-119.

Godwin, R. J. 2007. A review of the effect of implement geometry on soil failure and implement forces. Soil Tillage Res. 97(2): 331-340.

Hunt, D. 2001. Farm Power and Machinery Management. Lowa State University Press, USA.

Jokiniemi, T., H. Rossner and J. Ahokas. 2012. Simple and cost effective method for fuel consumption measurements of agricultural machinery. Agron. Res. 10: 97-107.

Karimiinchebron, A., M. S. R. Seyedi and R. T. Koloor. 2012. Investigating the effect of soil moisture content and depth on the draught, specific draught and drawbar power of a light tractor. Int. Res. J. Appl. Basic. Sci. 3(11): 2289-2293.

Khadr, K. A. A. 2008. Effect of some primary tillage implement on soil pulverization and specific energy. Misr J. Agric. Eng. 25(3): 731-745.

Kudabo, E. and L. Gabdamosi. 2012. Effects of forward speed on the performance of a disc plough. J. Sci. Multidiscip. Res. 4: 25-32.

Massey Ferguson. 2006. Operator Instruction Book. Issue 2. 8400 EAME. Massey Ferguson, Turkey.

Mileusnic, Z. I., D. V. Petrović and M. S. Đević. 2010. Comparison of tillage systems according to fuel consumption. Energy. 35(1): 221-228.

Moeinfar, A., S. R. Mousavi-Seyedi and D. Kalantari. 2014. Influence of tillage depth, penetration angle and forward speed on the soil/ thin-blade interaction force. Agric. Eng. Int. CIGR. J. 16(1): 69-74.

Moitzi, G., H. Wagentristl, K. Refenner, H. Weingartmann, G. Piringer, J. Boxberger and A. Gronauer. 2014. Effects of working depth and wheel slip on fuel consumption of selected tillage implements. Agric. Eng. Int. CIGR. J. 16(1): 182-190.

Moitzi, G., H. Weingartmann and J. Boxberger. 2006. Effects of Tillage Systems and Wheel Slip on Fuel Consumption. Vol. 7. The Union of Scientists-rousse: Energy Efficiency and Agricultural Engineering, Rousse, Bulgaria. p237-242.

Musa, D. S., J. Musa and D. Ahmad. 2012. Mechanization effect on farm practices in Kwara State, North central Nigeria. IOSR. J. Eng. 2(10): 79-84.

Namdari, M., S. Rafiee and A. Jafari. 2011. Using the FMEA method to Optimize fuel consumption in tillage by moldboard plow. Int. J. Appl. Eng. Res. 1(4): 734-742.

Osman, A. N., L. Xia and Z. Dongxing. 2011. Effects of tilt angle of disk plough on some soil physical properties, work rate and wheel slippage under light clay soil. Int. J. Agric. Biol. Eng. 4(2): 29-35.

Rashidi, M., I. Najjarzadeh, B. Jaberinasab, S. M. Emadi and M. Fayyazi. 2013. Effect of soil moisture content, tillage depth and operation speed on draft force of moldboard plow. Middle East J. Sci. Res. 16(2): 245-249.

Sahay, J. 2004. Elements of Agricultural Engineering. $4^{\text {th }}$ ed. A. K. Jain (Prop.) Publisher, New Delhi.

Stajnko, D., M. Lakota, F. Vucajnk and R. Bernik. 2009. Effects of different tillage systems on fuel savings and reduction of $\mathrm{CO}_{2}$ emissions in production of silage corn in Eastern Slovenia. Pol. J. Environ. Stud. 18(4): 709-714.

Yahya, A., M. Zohadie, A. F. Kheiralla, S. K. Giew and N. E. Boon. 2009. Mapping system for tractor-implement performance. Comput. Electron. Agric. 69(1): 2-11. 